Zeszyty Naukowe Szkoły Głównej Gospodarstwa Wiejskiego w Warszawie

Problemy Rolnictwa Światowego tom 18 (XXXIII), zeszyt 2, 2018: 322-333

DOI: $10.22630 /$ PRS.2018.18.2.59

Danuta Zawadzka ${ }^{1}$

Instytut Ekonomiki Rolnictwa i Gospodarki Żywnościowej - Państwowy Instytut

Badawczy w Warszawie

\title{
Rynek wieprzowiny w Rosji w latach 1990-2017
}

\section{Pork Market in Russia from 1990-2017}

\begin{abstract}
Synopsis. Celem analizy jest zidentyfikowanie kluczowych zmian, jakie nastąpiły na rosyjskim rynku wieprzowiny w latach 1990-2017. Badaniem objęto wszystkie elementy rynku, podejmując jednocześnie próbę odpowiedzi na dwa pytania: Czy rosnąca produkcja mięsa wieprzowego pozwoli na uzyskanie przez Rosję samowystarczalności w najbliższych latach? oraz czy Rosja ma szansę na przekształcenie się z importera netto w eksportera netto wieprzowiny? Podstawę oceny stanowiły dane pochodzące z rosyjskich Roczników Statystycznych oraz z publikacji amerykańskich Foreign Agricultural Service USDA. Do pomiaru dynamiki wykorzystano indeksy o stałej i zmiennej podstawie. Analiza pozwoliła na stwierdzenie, że największy wpływ na rosyjski rynek wieprzowiny wywarły subsydia prowadzące do wzrostu pogłowia i produkcji wieprzowiny w ostatnich dziesięciu latach. Pozwoli to na osiągnięcie samowystarczalności w najbliższych latach, ale pozycja eksportera netto może być osiągnięta $\mathrm{w}$ dalszej przyszłości.
\end{abstract}

Słowa kluczowe: Rosja, rynek wieprzowiny, samowystarczalność

\begin{abstract}
The aim of the analysis is to identify the key changes that occurred on the Russian pork market from 1990-2017. The research covered all elements of the market, at the same time attempting to answer two questions: Will the growing production of pork allow Russia to achieve self-sufficiency in this area in the coming years? Does Russia have a chance to transform from a net importer into a net exporter of pork? The basis for the assessment data were taken from the Russian Statistical Yearbooks and from the US Foreign Agricultural Service USDA. Dynamics were indexed on fixed and variable bases. The analysis leads to the conclusion that the greatest impact on the Russian pork market would be the result of subsidies leading to the growth in the number of pigs and in pork production. This would allow Russia to achieve self-sufficiency in the coming years, with the position of net exporter as an achievable target in the future.
\end{abstract}

Key words: Russia, pig market, self-sufficiency

JEL Clasification: Q002, Q10, Q13, Q18

\section{Wprowadzenie}

Rynek wieprzowiny jest jednym z ważniejszych segmentów rynku mięsa w świecie, choć jego znaczenie w ostatnich ponad dwudziestu latach zmalało na rzecz drobiu. Z podobną sytuacją mamy do czynienia w wielu krajach, w tym także w Rosji. Udział wieprzowiny w rosyjskiej produkcji trzech podstawowych rodzajów mięsa (wołowina, wieprzowina i mięso drobiowe) obniżył się z 41\% w 1990 r. do 35\% średnio w latach 2015-2017. Udział wieprzowiny w spożyciu mięsa w Rosji pozostał jednak na tym samym

\footnotetext{
${ }^{1}$ dr, ul. Świętokrzyska 20,00-002 Warszawa, e-mail: Danuta.Zawadzka@ierigz.waw.pl; https://orcid.org/0000-0003-4762-9888
} 
poziomie ok. 35\%, gdyż drób częściowo wyparł wołowinę. W 1990 wołowina stanowiła $53 \%$ spożywanego w Rosji mięsa, a drób 12\%, podczas gdy średnio w latach 2015-2017 wołowina stanowiła $21 \%$, a drób $44 \%$.

Rosja jest ważnym uczestnikiem światowego rynku wieprzowiny. Należy do dziesiątki największych producentów i importerów tego mięsa. W 2016 r. zajmowała piąte miejsce w światowej produkcji wieprzowiny z udziałem $2,6 \%$. Jeśli weźmie się pod uwagę fakt, że udział czwartego producenta czyli Brazylii wynosił 3,4\% światowej produkcji wieprzowiny, to udział Rosji w światowej produkcji wieprzowiny można ocenić jako relatywnie duży.

Do niedawna Rosja była drugim (po Japonii) światowym importerem wieprzowiny. W 2013 r. tj. przed wprowadzeniem embargo na wieprzowinę z krajów UE (w tym z Polski), z USA, z Kanady i z innych krajów, Rosja importowała 883 tys. ton tego mięsa. Co prawda w ostatnich latach jej import obniżył się do ok. 300 tys. ton, ale i tak Rosja nadal pozostała czołowym importerem wieprzowiny w świecie. W 2016 r. znajdowała się na siódmym miejscu pod względem wielkości tego importu (Zawadzka, Pasińska, 2016 i 2017; Zawadzka, 2016). Przed 2014 r. Rosja była ważnym, choć nie głównym rynkiem zbytu polskich produktów wieprzowych. Eksport do Rosji stanowił ok. 6-8\% eksportowanych przez Polskę produktów wieprzowych. Udział eksportu thuszczu wieprzowego do Rosji w polskim eksporcie thuszczu był większy i wynosił 14-19\%. Eksport ten był o tyle ważny, że tłuszcz należy do grupy produktów trudno zbywalnych (Pasińska, 2017).

Podstawową przyczyną ograniczenia przez Rosję importu wieprzowiny był rozwój własnej produkcji. Dokonał się on głównie przy pomocy dotacji rządowych. Niebagatelną rolę odegrały też takie instrumenty, jak kontrola kwot importowych oraz embargo nałożone na niektóre kraje. Sądzić można, że jeśli w najbliższych latach utrzymałaby się podobna dynamika wzrostu produkcji, to Rosja mogłaby nie tylko osiagnąć zamierzony cel, a więc samowystarczalność w tym zakresie, ale mogłaby stać się eksporterem wieprzowiny.

\section{Dane i metody}

Niniejsze badania mają charakter poznawczy. Analizą objęto wszystkie elementy rosyjskiego rynku wieprzowiny, jak pogłowie trzody, produkcja wieprzowiny, handel zagraniczny trzodą i wieprzowiną, a także spożycie. Oceniono samowystarczalność w tym zakresie. Celem analizy jest ocena stanu bieżącego i zmian, jakie zaszły na rynku wieprzowiny w Rosji w latach 1990-2017. Okres, przyjęty do badań jest dostatecznie długi by móc wyodrębnić podstawowe tendencje na tym rynku. Ocenę przeprowadzono w oparciu o dane pochodzące z rosyjskich Roczników Statystycznych (Rosstat) oraz z publikacji amerykańskich Foreign Agricultural Service USDA. Do pomiaru dynamiki poszczególnych kategorii wykorzystano proste metody statystyczne, takie jak indeksy o stałej i zmiennej podstawie (Jóźwiak, Podgórski, 1998).

\section{Pogłowie trzody i produkcja wieprzowiny}

W latach 1990-2017 rosyjskie pogłowie trzody charakteryzowało się niejednolita długookresową tendencją a także zróżnicowanym natężeniem krótkookresowych wahań towarzyszących tym tendencjom. Dlatego na użytek niniejszej analizy cały okres podzielono na trzy podokresy o wyraźnie zaznaczających się odmiennych cechach. Pierwszy okres obejmuje 
lata 1990-1999, w których mamy do czynienia z tendencją spadkową pogłowia o wysokiej dynamice (rys. 1). Wówczas pogłowie trzody malało z roku na rok, a przeciętne roczne tempo jego spadku wynosiło 3,3\%. Długookresowej tendencji spadkowej towarzyszyły charakterystyczne dla „cyklu świńskiego” krótkookresowe wahania, które nie przejawiały się jednak wzrostem czy spadkiem pogłowia z roku na rok, a jedynie silniejszą lub słabszą dynamiką jego zmian. W okresie tym o opłacalności chowu trzody decydowały bowiem nie tylko relacje cen trzody do cen zbóż i pasz, tak jak to bywa zazwyczaj, ale także inne, znacznie istotniejsze czynniki. Nie dopuszczały one do wzrostu pogłowia, nawet w przypadku relatywnie dobrych warunków chowu. W takiej sytuacji słabsza stawała się jedynie dynamika spadku pogłowia. Gdy warunki chowu pogarszały się spadek pogłowia się wzmagał.

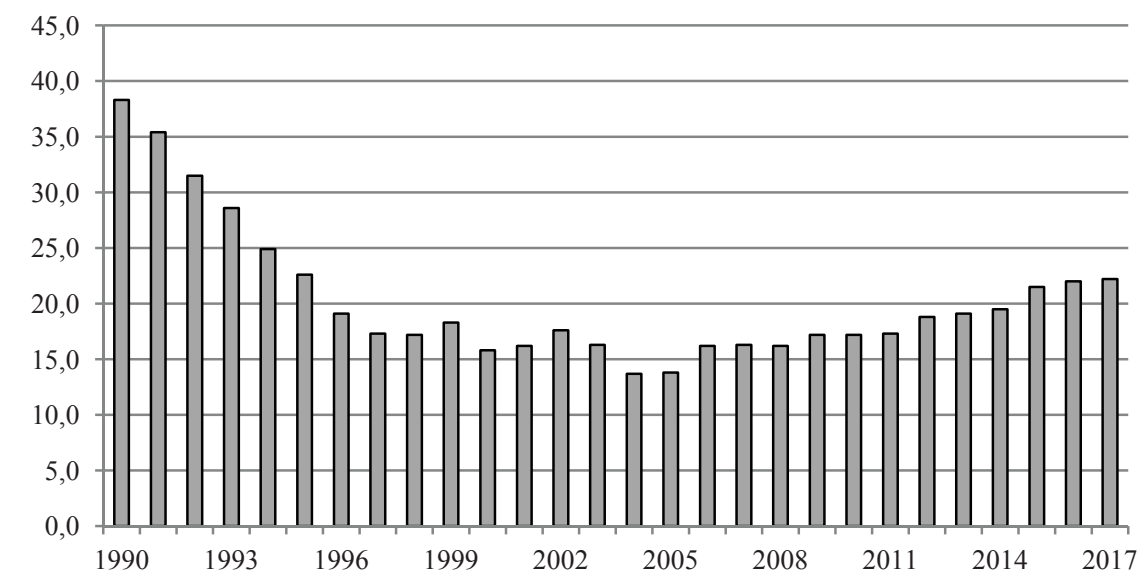

Rys. 1. Pogłowie trzody chlewnej w Rosji w latach 1990-2017. Stan w końcu roku, w mln sztuk

Fig. 1. Pig numbers in Russia from 1990-2017, at the end of year, in mln heads

Źródło: opracowanie własne na podstawie danych ROSSTAT.

Nasuwa się przypuszczenie, że podstawową determinantą spadkowej tendencji pogłowia była transformacja gospodarki w kierunku warunków rynkowych. Dawały więc o sobie znać nieefektywne warunki chowu, stosowane w poprzednim systemie. Za najważniejszy czynnik uznać należy redukcję wsparcia całej branży mięsnej przez państwo. W latach osiemdziesiątych produkcja mięsa była bowiem wysoko subsydiowaną gałęzią rosyjskiej gospodarki, co dotyczyło wszystkich rodzajów mięsa. W końcu lat osiemdziesiątych państwo pokrywało ok. $70 \%$ całkowitych kosztów produkcji i obsługi rynku mięsa (Ovchinnikov, Hoff, Reid, 1995).

$\mathrm{Na}$ występujące w tym okresie wahania pogłowia wskazują dane zaprezentowane na rys. 2, na którym przedstawiono dynamikę rocznych zmian pogłowia. Wskaźniki dynamiki wskazują, że maksymalne stany pogłowia pojawiły się w 1993 r., 1995 r. i w 1999 r. Minimalne stany pogłowia ujawniły się natomiast w 1992 r. i w 1994 r. Między pierwszym, a drugim maksymalnym stanem pogłowia upłynęły dwa, a między drugim a trzecim cztery lata. Różnica czasowa między minimalnymi stanami pogłowia wyniosła dwa lata.

Drugi okres to lata 2000-2008. Charakteryzował się on dalszą długookresową tendencją spadkową, ale w tym przypadku towarzyszyły jej wyraźnie zaznaczające się krótkookresowe wahania pogłowia. Każdy kolejny maksymalny stan pogłowia był jednak 
niższy od poprzedniego, co jest przejawem długookresowej tendencji spadkowej. Maksymalne stany pogłowia występowały w latach 2002 i 2006, a więc odstępy czasowe między jednym a drugim maksymalnym stanem pogłowia wynosiły cztery lata, a więc tyle co w klasycznym cyklu świńskim. Minimalne stany pogłowia wystąpiły natomiast w 2000, 2004 i w 2008 r., a więc także co cztery lata.

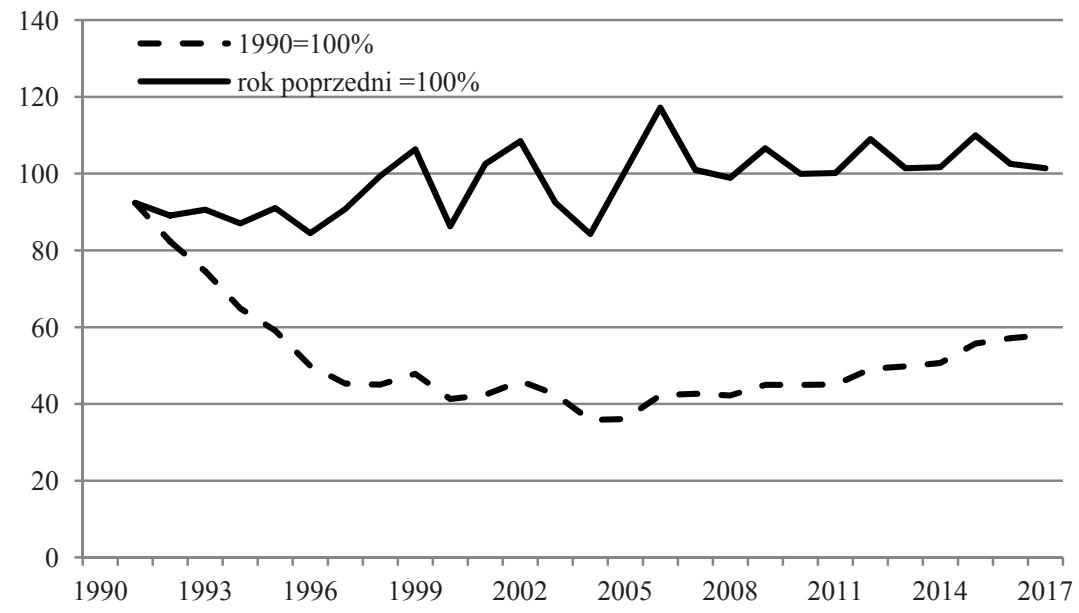

Rys. 2.Wskaźniki zmian pogłowia trzody chlewnej w Rosji, (w \%)

Fig. 2. Changes indicator in the number pigs in Russia, (in \%)

Źródło: opracowanie własne na podstawie danych ROSSTAT.

Trzeci okres obejmuje lata 2009-2017, dla których cechą charakterystyczną jest to, że w każdym kolejnym roku pogłowie trzody było większe niż w roku poprzednim, co jest wynikiem długookresowej tendencji wzrostowej. W niektórych latach widać jednak spowolnienie dynamiki wzrostu, podczas gdy w innych jej przyspieszenie. Największy wzrost pogłowia, mogący świadczyć o maksymalnym stanie pogłowia wystąpił w 2009, 2012 i w 2015 r., a więc regularnie co trzy lata. Z kolei relatywnie niewielki wzrost pogłowia, mogący świadczyć o minimalnym jego stanie wystąpił w 2011, 2014 i w 2016 r. Brak nominalnych spadków pogłowia, a widoczne jedynie osłabienie dynamiki jego wzrostu świadczy o wpływie czynników wspomagających opłacalność chowu. Były one na tyle silne, że nie dopuszczały do krótkookresowej redukcji pogłowia. Do czynników tych niewątpliwie zaliczyć można przywrócenie subsydiowania sektora.

W latach 2008-2016 subsydia do sektora wieprzowiny wyniosły łącznie 131 mld rubli. Najwyższe kwoty, bo po ok. 18 mld rocznie zostały skierowane w latach 2013-2016, a więc bezpośrednio przed- i po wprowadzeniu przez Rosję embargo na wieprzowinę. Subsydia obejmowały program wsparcia hodowców, zwrot kosztów pasz, zwrot nakładów inwestycyjnych na tworzenie centrum selekcji i genetyki oraz częściowy zwrot odsetek dla krótkoterminowych kredytów inwestycyjnych. Udział tego ostatniego instrumentu był największy i stanowił od 54\% całkowitych wydatków związanych z subsydiami w 2008 r. do $99 \%$ w 2010 r. (Vanderberg, 2016).

W rezultacie przeciętne roczne pogłowie wynoszące w latach 2009-2017 19,4 mln sztuk było o $21 \%$ większe niż przeciętne roczne pogłowie w latach 2000-2008 (16,0 mln 
sztuk), choć jednocześnie o 26\% mniejsze niż przeciętne, roczne pogłowie w latach 19901999 (26,1 mln sztuk) (tabela 1).

Tabela 1. Pogłowie trzody chlewnej (stan w końcu roku) i produkcja wieprzowiny w Rosji

Table 1. Number of pig (at the end of year) and pork production in Russia

\begin{tabular}{|c|c|c|c|c|c|c|}
\hline Okresy & $\begin{array}{l}\text { Pogłowie } \\
\text { trzody } \\
\text { w mln sztuk } \\
\text { (w końcu } \\
\text { roku) }\end{array}$ & $\begin{array}{l}\text { Okres } \\
\text { poprzedni } \\
=100\end{array}$ & $\begin{array}{l}\text { Lata } \\
1990-99 \\
=100\end{array}$ & $\begin{array}{l}\text { Produkcja } \\
\text { wieprzowiny } \\
\text { w tys. ton } \\
\text { wagi } \\
\text { poubojowej }\end{array}$ & $\begin{array}{l}\text { Okres } \\
\text { poprzedni } \\
=100\end{array}$ & $\begin{array}{l}\text { Lata } \\
1990-99 \\
=100\end{array}$ \\
\hline 1990-1999 & 26,1 & 100,0 & 100,0 & 1883 & 100,0 & 100,0 \\
\hline $2000-2008$ & 16,0 & 61,3 & 61,3 & 1605 & 85,2 & 85,2 \\
\hline $2009-2017$ & 19,4 & 121,3 & 74,3 & 2380 & 148,2 & 126,4 \\
\hline
\end{tabular}

Źródło: obliczenia własne na podstawie danych ROSSTAT.

Zmiany produkcji wieprzowiny były tożsame co do kierunku ze zmianami pogłowia, ale różne co do skali. W latach 2000-2008 spadek produkcji wieprzowiny był mniejszy niż pogłowia, ale jej wzrost w latach 2009-2017 był znacznie większy. W latach 2000 -2008 przeciętna, roczna produkcja wieprzowiny wyniosła 1605 tys. ton i była o $15 \%$ mniejsza niż w latach 1990-1999 (tabela 1). W latach 2009-2017 była ona o 48\% większa niż średnia, roczna produkcja w poprzednim okresie i o 26\% większa niż w latach 1990-1999. Z danych USDA/FAS (Leishman, 2017) wynika, że w 2018 r. produkcja ta może wynieść ok. $3 \mathrm{mln}$ ton. Gdyby tak było, to taka jej wielkość byłaby o 59\% większa niż średnia roczna wielkość produkcji w latach 1990-1999.

O poziomie produkcji decyduje nie tylko ilość ubijanych sztuk, ale także ich wydajność. Zgodnie z danymi Rosstatu (Russia in Figures, 2017) w 1992 r. na 1 sztukę ubijanych zwierząt przypadało $61 \mathrm{~kg}$ mięsa wieprzowego, podczas gdy w $2016 \mathrm{r}$. $202 \mathrm{~kg}$, a więc ponad trzykrotnie więcej. Z badań IERiGŻ-PIB wynika też, że w latach 1995-2015 Rosja, obok Brazylii, Kanady i USA była krajem, w którym dokonał się największy w świecie postęp w wydajności pogłowia (Zawadzka, 2016).

Niewątpliwie sprzyjają temu subsydia, których nadrzędnym celem jest wsparcie dużych obiektów i nowoczesnych technologii. Według Rosstatu, (Russia in Figures, 2017) w 2016 r. 84\% pogłowia trzody znajdowało się w dużych fermach przemysłowych będących organizacjami rolnymi, dalsze $15 \% \mathrm{w}$ gospodarstwach prywatnych, a pozostałe $1 \%$ w gospodarstwach chłopskich. W 2016 r. w 20 największych zakładach wyprodukowano łącznie $60 \%$ rosyjskiej produkcji wieprzowiny, w tym w trzech największych kompaniach przemysłowych 22\% (ABH „Miratorg”, Grupa „Rusagro” i Czerkizowo), a w pięciu największych 30\% (Leishman, 2017). Wpływ na koncentrację zakładów miało także występowanie wirusa ASF w małych gospodarstwach rolnych, które często $\mathrm{z}$ tego powodu rezygnowały $\mathrm{z}$ chowu. Redukcja pogłowia $\mathrm{w}$ tych gospodarstwach nie powodowała jednak ogólnego jego spadku, gdyż wzrost pogłowia w gospodarstwach dużych był na tyle wysoki, że z nadwyżką pokrywał ubytki pogłowia w gospodarstwach o małej skali produkcji. 


\section{Handel zagraniczny żywcem i mięsem wieprzowym}

Rosja jest importerem netto żywca i mięsa wieprzowego. Eksport tak żywych zwierząt, jak i mięsa prawie nie istnieje. Śladowe ilości trzody są sprzedawane okresowo. Eksport mięsa rozpoczął się w 2008 r. i chociaż rozwija się dość dynamicznie, to i tak jest marginalny. W 2016 r. wyeksportowano 25 tys. ton wieprzowiny. Było to trzy razy więcej niż rok wcześniej i ponad dwanaście razy więcej niż w $2008 \mathrm{r}$.

Import żywych zwierząt jest zmienny pod względem ilości (rys. 3). Największy import miał miejsce w latach 1990-1991 i wynosił średnio w roku 1583 tys. sztuk. W następnych latach został on ograniczony do kilku tysięcy sztuk. Na szerszą skalę rozwinął się ponownie w latach 2004-2013, przy czym najwyższy poziom importu miał miejsce w $2009 \mathrm{r}$. W strukturze tego importu dominowały prosięta o wadze mniejszej niż $50 \mathrm{~kg}$. Embargo nałożone na kraje Unii Europejskiej, a także wiele innych krajów (np. USA, Kanadę) w 2014 r. $^{2}$, ponownie zredukowało ten import.

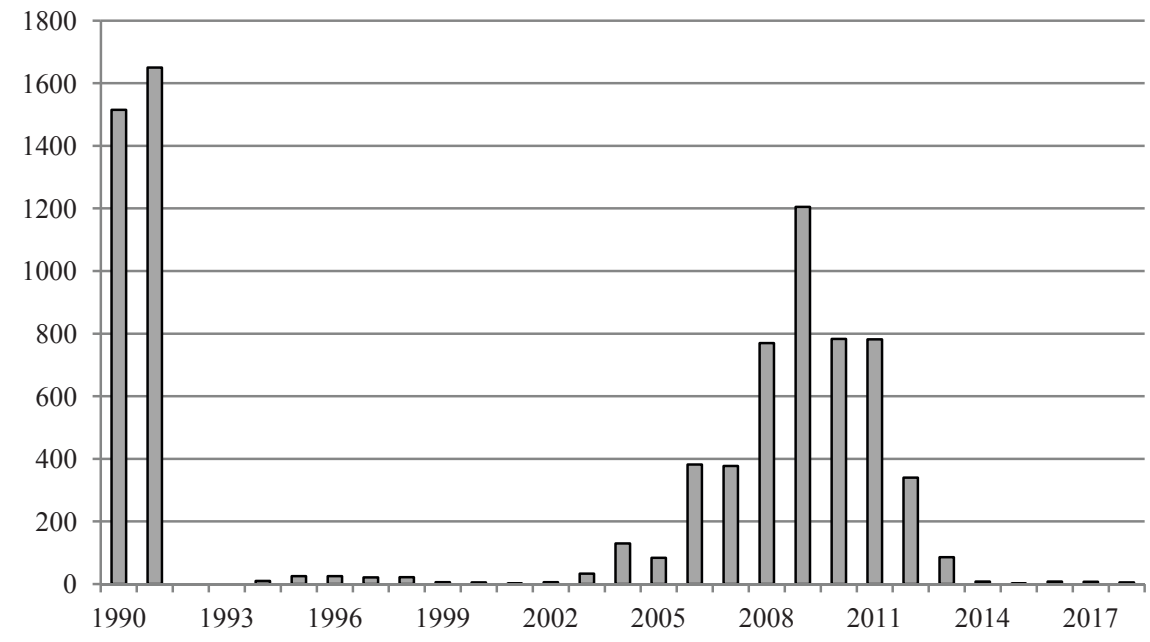

Rys. 3. Import trzody żywej (w tys. sztuk)

Fig. 3. Import of hogs (live animals, in 1000 Heads)

Źródło: opracowanie własne na podstawie danych USDA/FAS.

W badanym okresie import mięsa wieprzowego sukcesywnie wzrastał (rys. 4). W latach 2000-2008 był on o 66\% większy niż w latach 1990-1999 (tabela 2). W latach 20092017 wzrost importu w stosunku do lat 2000-2008 był mniejszy i wyniósł 55\%, o czym między innymi zadecydowało embargo. O ograniczeniu importu zadecydowała przyjęta na początku 2010 r. Doktryna Bezpieczeństwa Żywności (Доктрина продовольственной безопасности РФ). Zakładała ona zmniejszenie uzależnienia Rosji od importu produktów

\footnotetext{
2 Na początku 2014 r. Rosja wprowadziła embargo na wieprzowinę z Polski, a następnie z innych krajów Unii Europejskiej, a także USA, Kanady, Australii oraz Norwegii. W sierpniu 2015 r. embargo rozszerzono na Albanię i Czarnogórę oraz Islandię i Lichtenstein. W 2016 wśród krajów objętych embargiem znalazły się także Ukraina i Turcja.
} 
rolno-spożywczych. W dokumencie tym założono, że samowystarczalność Rosji, w zakresie mięsa ogółem i produktów mięsnych powinna być nie mniejsza niż $85 \%$.

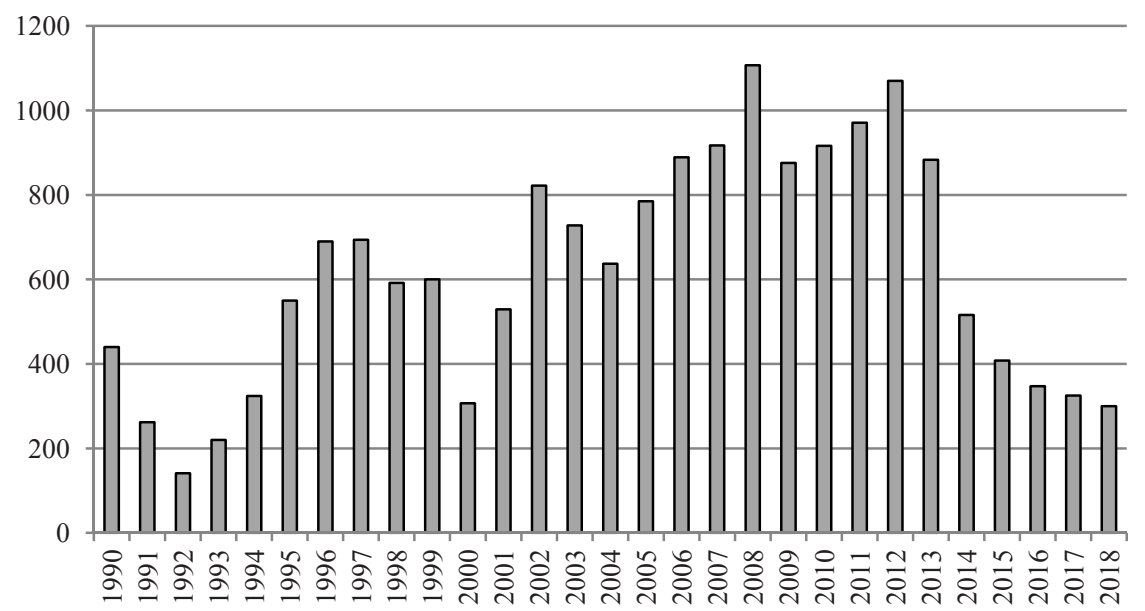

Rys. 4. Import wieprzowiny (w tys. ton)

Fig. 4. Import of pork (in $1000 \mathrm{MT}$ )

Źródło: opracowanie własne na podstawie danych USDA/FAS.

Tabela 2. Import żywca i mięsa wieprzowego

Table 2. Import of live pigs and pork

\begin{tabular}{l|cccccc}
\hline \multicolumn{1}{c|}{ Okresy } & $\begin{array}{c}\text { Żywe } \\
\text { zwierzęta } \\
\text { tys. sztuk }\end{array}$ & $\begin{array}{c}\text { Okres } \\
\text { poprzedni } \\
=100\end{array}$ & $\begin{array}{c}\text { Lata } \\
1990-99 \\
=100\end{array}$ & $\begin{array}{c}\text { Mięso } \\
\text { wieprzowe } \\
\text { w tys. ton }\end{array}$ & $\begin{array}{c}\text { Okres } \\
\text { poprzedni } \\
=100\end{array}$ & $\begin{array}{c}\text { Lata } \\
1990-99 \\
=100\end{array}$ \\
\hline $1990-1999$ & 327 & 100,0 & 100,0 & 451 & 100,0 & 100,0 \\
$2000-2008$ & 199 & 60,9 & 60,9 & 747 & 165,6 & 165,6 \\
$2009-2017$ & 358 & 179,9 & 109,5 & 701 & 155,4 & 93,8 \\
$2018^{1 /}$ & 5 & 1,4 & 1,5 & 400 & 88,7 & 57,1 \\
\hline \multicolumn{1}{l|}{ Prognoza USDA/FAS. } & & & & &
\end{tabular}

Źródło: obliczenia własne na podstawie danych USDA/FAS.

Biorąc pod uwagę cały rynek mięsa, założenie zawarte w Doktrynie zostało już osiągnięte, gdyż w 2016 r. samowystarczalność na rynku mięsa wyniosła ok. 90\%. Stało się to jednak głównie za sprawą mięsa drobiowego. W 2016 r., samowystarczalność w zakresie mięsa drobiowego wyniosła bowiem $97 \%$, podczas gdy w zakresie wieprzowiny $90 \%$, a wołowiny $72 \%$. Celem strategicznym jest jednak osiagniecie samowystarczalności w zakresie wieprzowiny w 2020 r. (Kavalev, 2012).

Na rynku wieprzowiny efekty wprowadzenia Doktryny zaczęły być widoczne dopiero po kilku latach od jej wprowadzenia. W latach 2010-2012 import wieprzowiny zwiększył się bowiem o $16,8 \%$ (w tempie ok. 5\% rocznie). Wzrost importu postępował pomimo deprecjacji rubla i niższych cen ropy. Dopiero w 2013 r. ograniczony on został do 883 tys. ton, co oznaczało, że był mniejszy niż w 2012 r. o 17,5\% i o 4\% mniejszy niż w 2010 r. 
Spadek importu nie oznaczał jedynie jego spadku w wymiarze nominalnym, ale także w relacji do spożycia, czemu sprzyjał równoczesny wzrost produkcji wieprzowiny. W latach 2000-2008 rosyjski import wieprzowiny (bez importu żywych zwierząt) stanowił 34\% konsumpcji wieprzowiny. W latach 2009-2017 udział ten obniżył się do $23 \%$, w tym do $11 \%$ w 2016 r. i $10 \%$ w 2017 r.

Udział importu wieprzowiny w jej spożyciu (rys. 5), wynoszący średnio w latach 2015-2017 r. ok. $11,5 \%$ był nieco wyższy niż w latach 1990-1994 (10,4\%), czyli w okresie przebudowy gospodarki. Nominalny wzrost produkcji, który nastąił w odniesieniu do tamtego okresu umożliwił jednak na wzrost spożycia jednostkowego $\mathrm{z}$ ok. 14 $\mathrm{kg} /$ mieszkańca (lata 1990-1994) do ok. $20 \mathrm{~kg} /$ mieszkańca w latach 2015-2017, a więc o ok. $6 \mathrm{~kg} /$ mieszkańca, przy podobnym udziale importu spożyciu.

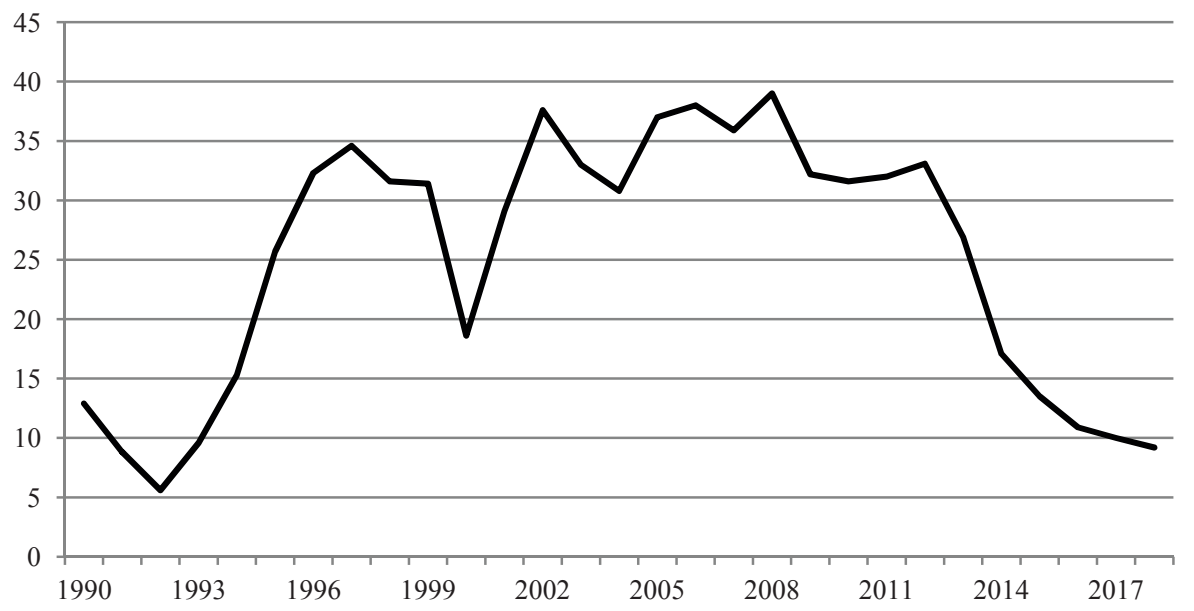

Rys. 5. Udział importu w konsumpcji wieprzowiny, (w \%)

Fig. 5. Share of pork imports in pork consumption, (in \%)

Źródło: opracowanie własne na podstawie danych USDA/FAS.

Embargo nałożone przez Rosję na import wieprzowiny z Unii Europejskiej, w tym z Polski, a także na inne kraje (m.in. USA, Kanadę, Australię) w największym stopniu przyczyniło się do zmiany kierunków geograficznych rosyjskiego importu. W $2013 \mathrm{r}$. import wieprzowiny z krajów, na które nałożono embargo stanowił ok. $74 \%$ rosyjskiego importu wieprzowiny. Do najważniejszych eksporterów wieprzowiny na ten rynek należała Brazylia, Dania, Niemcy i Hiszpania. Po wprowadzeniu embargo najwięcej zyskała Brazylia, której udział w rosyjskim imporcie wieprzowiny zwiększył się w latach 20122016 z ok. $50 \%$ do $90 \%$. Pozostałe kraje eksportujace wieprzowinę do Rosji to Chile, Białoruś, Serbia, Paragwaj i Argentyna. Ich udział w tym rynku jest jednak marginalny. 


\section{Spożycie wieprzowiny oraz samowystarczalność w zakresie wieprzowiny}

Spożycie tak globalne, jak i jednostkowe są pochodną krajowej produkcji wieprzowiny oraz jej importu. W Rosji, siła oddziaływania obu tych czynników była zmienna. W latach dziewięćdziesiątych spożycie wieprzowiny zmniejszało się (rys. 6), gdyż zmniejszała się produkcja, a import był relatywnie niski. W latach 2000-2008 spożycie rosło, pomimo dalszego spadku produkcji. Wówczas o poziomie spożycia i o jego wzroście decydował rosnący import wieprzowiny, tak absolutny jak i względny (w odniesieniu do konsumpcji). W latach 2009-2017 spożycie wieprzowiny nadal charakteryzowało się tendencją wzrostową. Tym razem jednak o jego wzroście decydowała rosnąca produkcja wieprzowiny, gdyż import tak absolutny, jak i względny zmniejszał się (rys. 4, 5).

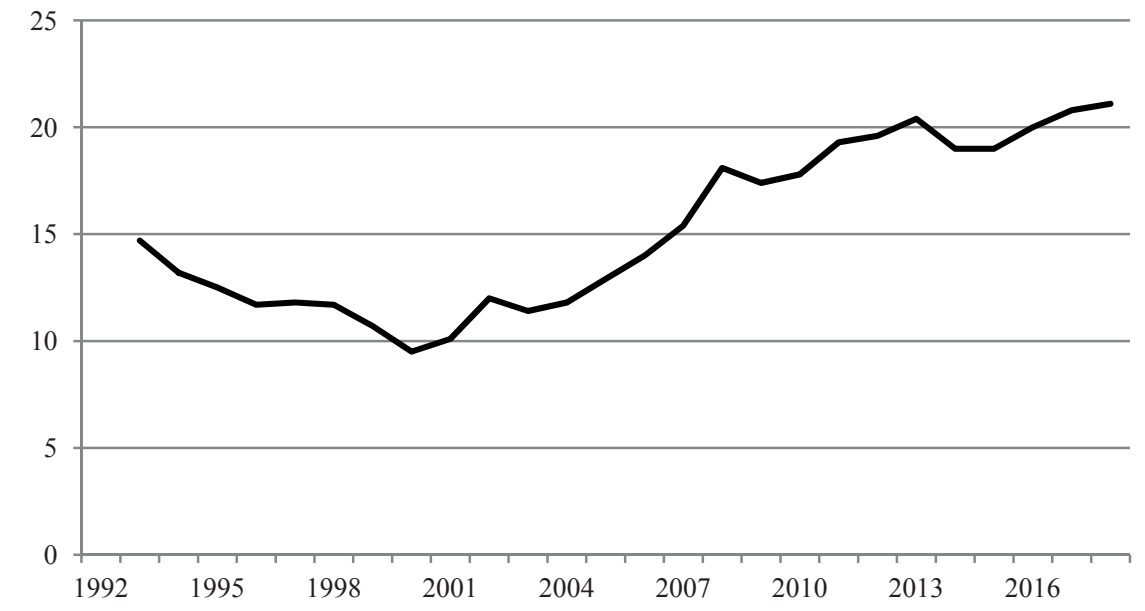

Rys. 6. Spożycie wieprzowiny w kg/mieszkańca

Fig. 6. Pork consumption in kilograms/person

Źródło: opracowanie własne na podstawie danych OECD.

Spożycie wieprzowiny przypadające na 1 mieszkańca wzrosło z $12,3 \mathrm{~kg}$ średnio w latach 1990-1999 do 19,3 kg w latach 2009-2017, a więc o 7 kg/mieszkańca (tabela 3). Wzrost spożycia w tych latach odbywał się w warunkach długookresowego wzrostu cen detalicznych wieprzowiny (rys. 7). Był on jednak możliwy z uwagi na spadek bezrobocia oraz wzrost realnych dochodów dyspozycyjnych ludności.

Zgodnie z danymi Rosstatu (Российский статистический ежегодник, 2017), stopa bezrobocia, która w 2000 r. wynosiła 9,6\%, w 2010 r. zmalała do 7,5\% i na podobnym poziomie utrzymała się do 2016 r. Z kolei wskaźnik dynamiki realnych dochodów dyspozycyjnych ludności (przy założeniu że 1995 r. = 100\%), w 2000 r. wynosił 87,9\%, w 2010 r. 215,6\%, w 2014 r. był najwyższy gdyż wyniósł 234,1\%, a w 2016 r. obniżył się do $213,6 \%$. Spadek dochodów realnych w 2000 r. o 12,1\% wpłynął niewątpliwie na spadek spożycia, a w konsekwencji na spadek importu. Wzrost realnych dochodów ludności w następnych latach umożliwił jednak dalszy wzrost spożycia. 
Tabela 3. Spożycie wieprzowiny

Table 3. Pork consumption

\begin{tabular}{l|cccccc}
\hline \multicolumn{1}{c|}{ Okresy } & Okres & Lata 1990- & w & \multicolumn{2}{c}{ Okres } & Lata 1990- \\
& w tys. ton & $\begin{array}{c}\text { poprzedni } \\
=100\end{array}$ & $\begin{array}{c}99 \\
=100\end{array}$ & $\mathrm{~kg} /$ mieszkańca & $\begin{array}{c}9 \\
=100\end{array}$ & $=100$ \\
\hline $1990-1999$ & 2334 & 100,0 & 100,0 & 12,3 & 100,0 & 100,0 \\
$2000-2008$ & 2198 & 94,2 & 94,2 & 12,8 & 104,1 & 104,1 \\
$2009-2017$ & 3073 & 139,8 & 131,7 & 19,3 & 150,6 & 150,6 \\
$2018^{1 /}$ & 3275 & 106,6 & 140,3 & 21,1 & 109,3 & 109,3 \\
\hline
\end{tabular}

\section{1/ Prognoza USDA/FAS}

Źródło: Obliczenia własne na podstawie danych USDA/FAS

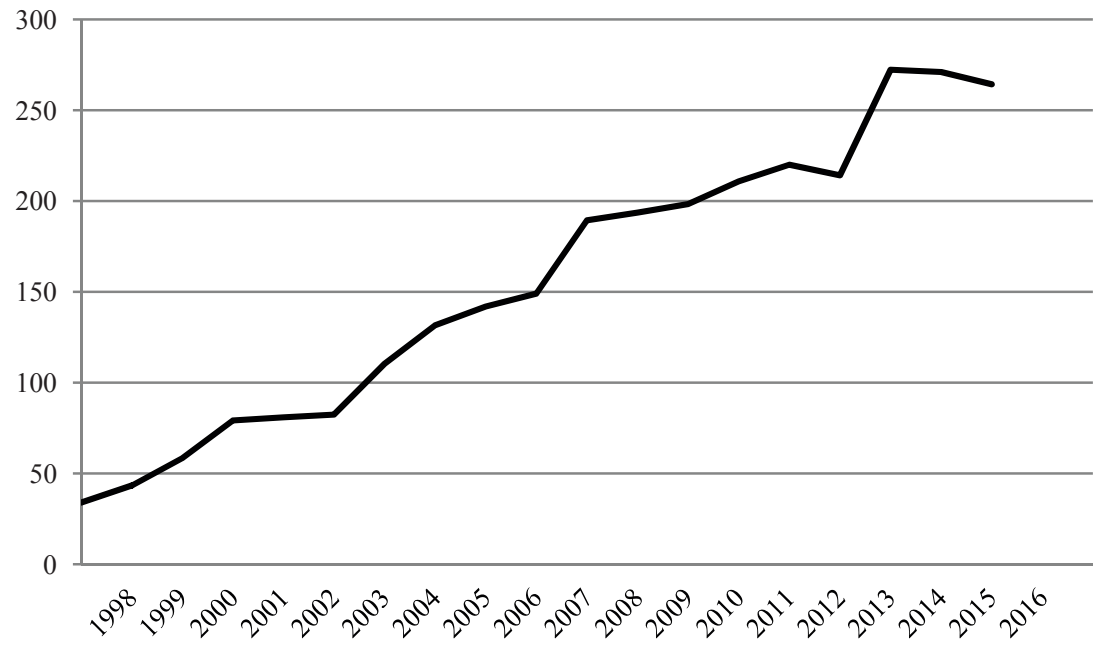

Rys. 7. Ceny wieprzowiny (poza mięsem bez kości) w RUB/kg

Fig. 7. Pork prices (without boneless meat) in RUB/kg

Źródło: opracowanie własne na podstawie danych Цены в России (2016).

W Rosji, relacja produkcji do spożycia, a więc syntetyczny wskaźnik samowystarczalności ${ }^{3}$ świadczy o braku samowystarczalności w zakresie wieprzowiny (tabela 4). Wskaźnik ten początkowo obniżył się z 81\% średnio w latach 1990-1999 do $73 \%$ w latach 2000-2008, a następnie wzrósł do 77\% średnio w latach 2009-2017, w tym w 2016 r. wyniósł 90\%, a w 2017 r. 91\%. Zgodnie z prognozą FAS/USDA w 2018 r. może on wynieść $92 \%$. Jeśli produkcja rozwijałaby się $\mathrm{w}$ tempie ok.1,4\% rocznie, a spożycie ok. $0,4 \%$, a więc w takim tempie jak założone na 2018 r., to za około 10 lat Rosja mogłaby być samowystarczalna w produkcji wieprzowiny. Może to nastapić wcześniej, gdyby tempo

\footnotetext{
${ }^{3}$ Syntetyczny wskaźnik samowystarczalności definiowany jest jako stosunek wolumenu produkcji globalnej czy krajowej danego produktu do wolumenu zużycia globalnego czy krajowego tego produktu. W niniejszym opracowaniu posłużono się spożyciem, a nie zużyciem całkowitym danego produktu ze względu na trudności związane z pozyskaniem odpowiednich danych.
} 
wzrostu produkcji było wyższe. Przy założeniu, że tempo wzrostu produkcji w latach 20182020 będzie takie, jak średnie roczne tempo wzrostu produkcji w okresie 2009-2017 (6\%), podobnie jak średnie roczne tempo wzrostu spożycia $(2,5 \%)$, to w 2020 r. poziom samowystarczalności mógłby wynieść $98 \%$, a więc zamierzony cel nie zastałby osiagnięty. Samowystarczalność mogłaby jednak wynieść $101 \%$ w 2021 r. Przy rocznym poziomie spożycia 24-25 kg/mieszkańca (o 4-5 kg/mieszkańca wyższym niż w 2017 r.) Rosja mogłaby wówczas dysponować niewielką nadwyżką wieprzowiny. Gdyby jednak z powodów ekonomicznych lub innych wzrost spożycia został osłabiony to nadwyżka mogłaby pojawić się wcześniej. Aby jednak nie dopuścić do osłabienia spożycia wieprzowiny w Rosji planowana jest pomoc żywnościowa (Kovalev, 2012).

Tabela 4. Wskaźnik samowystarczalności w zakresie wieprzowiny

Table 4. Self-sufficiency indicator for pork

\begin{tabular}{l|ccc}
\hline \multicolumn{1}{c|}{ Okresy } & Produkcja w tys. ton & Spożycie (w tys. ton) & Wskaźnik samowystarczalności \\
\hline $1990-1999$ & 1883 & 2334 & 80,7 \\
$2000-2008$ & 1605 & 2198 & 73,0 \\
$2009-2017$ & 2380 & 3073 & 77,4 \\
$2018^{1 /}$ & 3000 & 3275 & 91,6 \\
\hline \multicolumn{2}{l}{ 1/ Prognoza USDA/FAS }
\end{tabular}

Źródło: obliczenia własne na podstawie danych USDA/FAS.

Eksport wieprzowiny przez Rosję mógłby być utrudniony z uwagi na obecność choroby ASF, choć nie wykluczone, że za kilka lat Rosja upora się z tym problemem. Wprowadzany jest bowiem program rejestracji i kontroli świń na działkach prywatnych. Podjęto kroki zmierzające do prawnego uregulowania zakazu trzymania 1-2 świń na działkach prywatnych (Kovalev, 2012). W 2016 r. Rosja zaczęła pilotażowy eksport wieprzowiny m.in. do Egiptu, Mongolii i Zjednoczonych Emiratów Arabskich. Osiagnięcie statusu eksportera netto wymagać jednak będzie dalszego dynamicznego rozwoju produkcji, co będzie głównie zależało od wielkości środków pieniężnych skierowanych do sektora, zapewne w nowym programie po 2020 r., jeśli taki powstanie. Atutem Rosji jest to, że pod wpływem dotychczasowych programów wsparcia znacząca część pogłowia utrzymywana jest w gospodarstwach o dużej skali i produkowana jest przy pomocy nowoczesnych technologii. Dokonano też koncentracji produkcji i ubojów trzody. W 2020 r. 20 największych firm ma odpowiadać za 76\% produkcji wieprzowiny, a ok. $61 \%$ ubojów ma odbywać się w nowo wybudowanych zakładach (Kovalev, 2012).

\section{Podsumowanie}

Na podstawie przeprowadzonej analizy można stwierdzić, że podstawowy wpływ na rosyjski rynek wieprzowiny wywiera polityka państwa. Wśród instrumentów polityki rolnej stosowanych na rynku trzody za najważniejszy należy uznać subsydia. Ich usuniecie towarzyszace transformacji gospodarki doprowadziło do spadku pogłowia i produkcji wieprzowiny w latach 1997-1999. Z kolei ich przywrócenie w $2008 \mathrm{r}$. spowodowało, że średnie pogłowie trzody w latach 2009-2017 było o $21 \%$ większe niż w latach 2000-2008, a produkcja wieprzowiny o $48 \%$. Wytyczne dla rozwoju tego rynku nadała doktryna 
bezpieczeństwa żywnościowego, zgodnie z którą w 2020 r. poziom samowystarczalności w zakresie mięsa ogółem nie powinien być niższy niż $85 \%$. Cel ten w zasadzie został już osiagnięty, ale dążeniem jest osiagnięcie w 2020 r. pełnej samowystarczalności w zakresie wieprzowiny. Towarzysząca subsydiom kontrola kwot importowych, a także embargo na wieprzowinę wpłynęły na obniżenie importu oraz zmniejszenie jego udziału w spożyciu, przy wzroście spożycia wieprzowiny. W rezultacie wzrósł poziom samowystarczalności w zakresie wieprzowiny. Jeśli w najbliższych latach utrzyma się dotychczasowe tempo wzrostu produkcji i spożycia, to Rosja może stać się samowystarczalna w zakresie wieprzowiny, a także być jej eksporterem. Osiągniecie statusu eksportera netto będzie jednak wymagało dalszego dynamicznego rozwoju produkcji, co tak jak w poprzednich latach będzie zależało od wielkości środków pieniężnych skierowanych do sektora.

\section{Literatura}

Цены в России 2016. Статистический сборник (Prices in Russia 2016. Statistical compilation). Федеральная Служба Государственной Статистики, Москва 2016

Доктрина продовольственной безопасности Российской Федерации (Doctrine of the Russian Federation food security). (2010). УТВЕРЖДЕНА УКАЗОМ ПРЕЗИДЕНТА РОССИЙСКОЙ ФЕДЕРАЦИИ ОТ 30 ЯНВАРЯ 2010 Г. № 120

Jóźwiak, J., Podgórski, J. (1998). Statystyka od podstaw, (Statistics from scratch), PWE Warszawa 1998.

Kovalev, Y. (2012). Pig production in Russia, EPP Congress 2012, „Pig Production in Baltic Region - Chances and Challenges, Vilnius Lithuania 30.05-01.06.2012. Pobrane 12 czerwca 2017 z: http://www.pigproducer.net/ uploads/media/3_Jurij-Kovalev_.pdf.

Livestock and Poultry. World Markets and Trade, Foreign Agricultural Service (FAS) circular series 1990-2017.

Leishman, D. (2017). Russian Federation, Livestock and Products Annual, Gain Report USDA/FAS 28.11.2017.

OECD data, Meat consumption https://data.oecd.org/agroutput/meat-consumption.htm. Pobrano w lutym $2018 \mathrm{r}$.

Ovchinnikov, O., Hoff, R., Reid, S. (1995). Russian Federation, Livestock and Products Annual, Gain Report USDA/FAS 11.08.1995.

Pasińska, D. (2017). Zmiany w polskim handlu zagranicznym produktami wieprzowymi po wprowadzeniu przez Rosje embarga (Changes in the Polish Foreign Trade in Pork Products after introduction of the Russion Embargo). ZN SGGW, Problemy Rolnictwa Światowego, 17(2), 186-198; DOI: 10.22630/PRS.2017.17.2.38.

Российский статистический ежегодник (Russian Statistical Yearbook). (2017). Федеральная Служба Государственной Статистики, (РОССТАТ), Москва.

Russia in Figures (2017). Federal State Statistick Service (Rosstat).

Vanderberg, R. (2016). Russian Federation, Livestock and Products Annual, Gain Report USDA/FAS 02.09.2016.

Zawadzka, D., Pasińska, D. (2016 i 2017). Aktualny i przewidywany stan rynku wieprzowiny (The current and projected state of the pork market). W: Rynek Miesa. Stan i Perspektywy, nr 50-53, (red). D. Zawadzka, Analizy Rynkowe IERiGŻ-PIB, ARR (KOWR), MRiRW, 2016 i 2017.

Zawadzka, D. (2016 A). Rynek wieprzowiny (Pork market). W: Sytuacja na światowych rynkach mięsa i produktów mleczarskich oraz jej wpływ na rynek krajowy i możliwości jego rozwoju, (red.) Stanisław Stańko, Monografie Programu Wieloletniego nr 31, IERiGŻ-PIB, Warszawa, 58-70.

Do cytowania / For citation:

Zawadzka D. (2018). Rynek wieprzowiny w Rosji w latach 1990-2017. Problemy Rolnictwa Światowego, 18(2), 322-333; DOI: 10.22630/PRS.2018.18.2.59

Zawadzka D. (2018). Pork Market in Russia from 1990-2017 (in Polish). Problems of World Agriculture, 18(2), 322-333; DOI: 10.22630/PRS.2018.18.2.59 